\title{
INCORPORATING SUSTAINABILITY AND RESILIENCY CONTENT INTO CIVIL ENGINEERING UNDERGRADUATE CURRICULUM
}

\section{Prof. Bhaskar Chittoori P.E., Boise State University}

Dr. Bhaskar Chittoori joined the faculty of the Department of Civil Engineering at Boise State University in the fall of 2013. He is the director of the Sustainable and Resilient Geotechnical Engineering (SuRGE) Research Laboratory. His research focusses on solving complex geomechanics issues related to problematic clayey soils via experimental and numerical modeling studies. Some of his research focus includes, microbiological and chemical modification of soils, advanced soil testing \& interpretation, and finite element modeling of soil systems. He also conducts research on sustainability and resiliency assessments of various civil infrastructure and thrives on educating the next generation of civil engineers prepared to tackle future challenges. He received about two million (PI/Co-PI) in grant funding from various state and federal agencies and has published in noteworthy journals. He is a licensed civil engineer in the states of Texas and Idaho, he is also a member of Chi Epsilon and Tau Beta Pi Honor Societies. He is also the founding president of the ASCE's Southern Idaho Geo-Institute chapter.

\section{Dr. Noah Salzman, Boise State University}

Noah Salzman is an Assistant Professor at Boise State University, where he is a member of the Electrical and Computer Engineering Department and IDoTeach, a pre-service STEM teacher preparation program. His work focuses on the transition from pre-college to university engineering programs, how exposure to engineering prior to matriculation affects the experiences of engineering students, and engineering in the K-12 classroom. He has worked as a high school science, mathematics, and engineering and technology teacher, as well as several years of electrical and mechanical engineering design experience as a practicing engineer. He received his Bachelor of Science degree in Engineering from Swarthmore College, his Master's of Education degree from the University of Massachusetts, and a Master's of Science in Mechanical Engineering and Doctorate in Engineering Education from Purdue University.

\section{Dr. Robert Hamilton P.E., Boise State University}

Dr. Hamilton has been with Boise State University since 1995, where he helped found the Civil Engineering Department.

\section{Dr. Debakanta Mishra, Oklahoma State University Dr. Sondra M Miller, Boise State University}

Dr. Sondra M. Miller is an associate professor in the Department of Civil Engineering within the College of Engineering at Boise State University. Miller earned a B.S. in Civil Engineering and a M.S. in Environmental Engineering from the State University of New York at Buffalo, and a Ph.D. in Environmental Engineering from the University of Iowa. Her educational research interests are focused on methods to attract and retain women and underrepresented minorities in STEM fields. 


\title{
INCORPORATING SUSTAINABILITY AND RESILIENCY CONTENT INTO CIVIL ENGINEERING UNDERGRADUATE CURRICULUM
}

\begin{abstract}
Sustainability and Resiliency (S\&R) concepts have risen to prominence in recent years. The concept of incorporating sustainability into civil engineering became popular in the late 1980s during the advent of the construction industry's first sustainable assessment system for office buildings with more or less equally weighted environmental, economic, and social aspects[1]. The concept of resilience is usually associated with extreme events during the life of a civil infrastructure, and the ability to resist loss of functionality and recover quickly from these events. In the past decade, engineers have achieved a reduction in direct and indirect losses from hazards by incorporating resilience concepts into their work. Teaching these concepts to future civil engineers is of paramount importance. Faculty at several institutions are leveraging stand-alone S\&R educational materials such as those available through the Center for Sustainable Engineering [2], Sustainable Engineering Education Key Resources Repository [3] and other such sources. However, there are several issues with this approach. For example, most civil engineering programs implement sustainability concepts in freshman, sophomore and senior years, which clearly indicates a junior year gap. Students gain sub-discipline specific knowledge during the junior year. It would be prudent to show students how S\&R applies in each of these sub-disciplines. Existing piecemeal approaches to incorporating S\&R concepts and skills at different points in the curriculum leads to students struggling to develop a coherent understanding of S\&R. In addition, many existing efforts are focused on sustainability content with very limited focus on resiliency aspects.

These issues suggest a clear need for improvement. This paper will discuss one such improvement effort where S\&R concepts are permeated into the CE curriculum via Active Learning Modules (ALMs) and Design Tasks (DTs) developed to be incorporated into existing $\mathrm{CE}$ courses from freshman to senior year. A total of twelve courses were selected for this purpose and separate ALMs for sustainability and resiliency were developed for each of freshmen through junior-level courses. Design tasks were developed for the senior-level classes with the intent to challenge students to apply the concepts taught in earlier courses. The paper will include descriptions of each of the ALMs and how they are incorporated in each course; moreover, experience gained while developing and implementing these modules will also be shared. To understand the effects of incorporating S\&R content into the CE curriculum via these ALMs, a variety of qualitative and quantitative data were collected. Preliminary results show both a strong need for instruction related to S\&R concepts and establish the effectiveness of the ALM approach.
\end{abstract}

\section{INTRODUCTION}

Sustainable infrastructure balances economic, ecological, and societal needs by being responsive to community impact, human health, and the environment. Professionals in this science, technology, engineering, and mathematics (STEM) domain can consider both when selecting 
infrastructure materials or when building, repairing, or removing it. Resilient infrastructure lasts. It retains partial or full function and structural capacity and also supports interconnected ecosystems and social systems under increasingly challenging climate events such as earthquakes, wildfires, or hurricanes, and ensures access to critical transportation, energy, and water. Several studies presented at the 2014 American Society of Civil Engineers International Conference on Sustainable Infrastructure[4] demonstrated the societal need for sustainable and resilient (S\&R) infrastructure and the demand for workers with this expertise, especially in light of the negative impacts of recent natural hazards around the world. Future civil engineers must be equipped with the required knowledge to deliver on this need. Faculty at several institutions are leveraging stand-alone S\&R educational materials such as those available through the Center for Sustainable Engineering, Sustainable Engineering Education Key Resources Repository and other such sources. However, there are several issues with this approach. For example, most civil engineering programs implement sustainability concepts in freshman, sophomore and senior years, which clearly indicates a junior year gap. Students gain sub-discipline specific knowledge during the junior year. It would be prudent to show students how S\&R applies in each of these sub-disciplines. Existing piecemeal approaches to incorporating S\&R concepts and skills at different points in the curriculum leads to students struggling to develop a coherent understanding of S\&R. In addition, many existing efforts are focused on sustainability content with very limited focus on resiliency aspects.

Through this NSF funded project, the authors are exploring a new strategy of teaching S\&R concepts to civil engineering students. The goal is to permeate the $\mathrm{S} \& \mathrm{R}$ concepts into the CE curriculum by injecting content into existing curriculum from freshman to senior years. To achieve this goal, the research team selected twelve courses that range from freshmen to senior years from the current Boise State Civil Engineering curriculum to introduce S\&R concepts via active learning modules designed to help students understand the underlying philosophies of S\&R and their importance to civil infrastructure. Eight of the twelve courses are required courses while the remaining four are senior electives. This paper details the procedures followed to develop and implement the ALMs and DTs.

\section{Review of existing literature}

A thorough review of the current state of the art sustainability and resiliency assessments of civil infrastructure was performed to establish the key concepts to be introduced to the students. The review included both national and international databases to capture all aspects of S\&R. A document was prepared summarizing this review. Based on this review it was identified that certain concepts such as life cycle analysis and risk and reliability should be introduced early in the curriculum, so that they can be used later in discipline specific assessments in junior and senior years. Table 1 shows the planned concept delivery for each course along with the corresponding learning objectives.

This review also included a search for existing learning modules that focused on delivering S\&R concepts to CE students. It was found that there were a few modules that focused on delivering sustainability concepts in environmental engineering especially in wastewater treatment, but a lack of modules dealing with resiliency concepts throughout the curriculum. 
Table 1 Planned concept delivery in each course along with the primary learning objective of the module

\begin{tabular}{|c|c|c|c|}
\hline \multirow{2}{*}{$\begin{array}{l}\text { Course \# } \\
\text { (Degree } \\
\text { Standing) }\end{array}$} & \multirow{2}{*}{ Course Title } & \multicolumn{2}{|c|}{ Primary Learning Objective } \\
\hline & & Sustainability & Resiliency \\
\hline $\begin{array}{l}\text { ENGR } 120 \\
\text { (Freshmen) }\end{array}$ & $\begin{array}{l}\text { Introduction to } \\
\text { Engineering }\end{array}$ & $\begin{array}{l}\text { Understand the role of } \\
\text { sustainability in engineering } \\
\text { design }\end{array}$ & $\begin{array}{l}\text { Understand how resiliency impacts } \\
\text { engineering design }\end{array}$ \\
\hline $\begin{array}{c}\text { CE 280 } \\
\text { (Sophomore) }\end{array}$ & $\begin{array}{l}\text { Civil Engineering } \\
\text { Case Studies }\end{array}$ & $\begin{array}{l}\text { Understand the role of } \\
\text { sustainability as it applies to } \\
\text { civil engineering }\end{array}$ & $\begin{array}{l}\text { Understand the role of resiliency as it } \\
\text { applies to civil engineering }\end{array}$ \\
\hline $\begin{array}{c}\text { CE 282 } \\
\text { (Sophomore) }\end{array}$ & $\begin{array}{l}\text { Engineering } \\
\text { Practice }\end{array}$ & $\begin{array}{l}\text { Learn the use of life cycles } \\
\text { analysis to compare design } \\
\text { alternatives }\end{array}$ & $\begin{array}{l}\text { Learn the use of Monte Carlo simulations } \\
\text { to perform risk assessments in civil } \\
\text { engineering design }\end{array}$ \\
\hline $\begin{array}{l}\text { CE } 320 \\
\text { (Junior) }\end{array}$ & $\begin{array}{l}\text { Principles of } \\
\text { Environmental } \\
\text { Engineering }\end{array}$ & $\begin{array}{l}\text { Understand the philosophies } \\
\text { and definitions of sustainability } \\
\text { as applicable to environmental } \\
\text { engineering }\end{array}$ & $\begin{array}{l}\text { Get a brief overview of computational } \\
\text { methods to determine resiliency, and how } \\
\text { resiliency implementation is applicable to } \\
\text { environmental engineering }\end{array}$ \\
\hline $\begin{array}{l}\text { CE } 330 \\
\text { (Junior) }\end{array}$ & Fluid Mechanics & $\begin{array}{l}\text { Show the importance of } \\
\text { sustainability by accounting for } \\
\text { minimum energy loss in fluid } \\
\text { systems. }\end{array}$ & $\begin{array}{l}\text { Appreciate difference in resilient and } \\
\text { non-resilient fluid systems. }\end{array}$ \\
\hline $\begin{array}{l}\text { CE } 340 \\
\text { (Junior) }\end{array}$ & $\begin{array}{l}\text { Engineering } \\
\text { Properties of } \\
\text { Construction } \\
\text { Materials } \\
\text { Laboratory } \\
\end{array}$ & $\begin{array}{l}\text { Understand the scope of } \\
\text { construction materials in civil } \\
\text { engineering towards } \\
\text { sustainable development of } \\
\text { civil infrastructure }\end{array}$ & $\begin{array}{l}\text { Have hands on experience in assessing } \\
\text { resilience of construction materials } \\
\text { through testing and application. }\end{array}$ \\
\hline $\begin{array}{l}\text { CE } 360 \\
\text { (Junior) }\end{array}$ & $\begin{array}{l}\text { Engineering } \\
\text { Properties of } \\
\text { Soils }\end{array}$ & $\begin{array}{l}\text { Understand scope of } \\
\text { geotechnical engineering } \\
\text { towards sustainable } \\
\text { development of civil } \\
\text { infrastructure }\end{array}$ & $\begin{array}{l}\text { Understand how resiliency concepts } \\
\text { applicable to geotechnical engineering } \\
\text { contribute to an entire system's } \\
\text { resilience. }\end{array}$ \\
\hline $\begin{array}{l}\text { CE } 370 \\
\text { (Junior) }\end{array}$ & $\begin{array}{l}\text { Transportation } \\
\text { Engineering } \\
\text { Fundamentals }\end{array}$ & $\begin{array}{l}\text { Understand the role of } \\
\text { transportation engineering } \\
\text { within the framework of } \\
\text { sustainable civil engineering } \\
\text { infrastructure }\end{array}$ & $\begin{array}{l}\text { Understand how resilient concepts } \\
\text { applicable to transportation engineering } \\
\text { contribute to an entire system's } \\
\text { resilience. }\end{array}$ \\
\hline $\begin{array}{l}\text { CE } 425 \\
\text { (Senior) }\end{array}$ & $\begin{array}{l}\text { Waste Water } \\
\text { Treatment Plant } \\
\text { Systems and } \\
\text { Design }\end{array}$ & $\begin{array}{l}\text { Understand the importance of } \\
\text { waste water treatment plant } \\
\text { designs to the concept of } \\
\text { sustainability. }\end{array}$ & $\begin{array}{l}\text { Understand the process of designing } \\
\text { resilient waste water treatment plants }\end{array}$ \\
\hline $\begin{array}{l}\text { CE } 440 \\
\text { (Senior) }\end{array}$ & $\begin{array}{l}\text { Pavement Design } \\
\text { and Evaluation }\end{array}$ & $\begin{array}{l}\text { Appreciate the impacts of a } \\
\text { design alternative on } \\
\text { sustainability by determining } \\
\text { the environmental impacts }\end{array}$ & $\begin{array}{l}\text { Evaluate resiliency of a design alternative } \\
\text { to compare and contrast with other design } \\
\text { alternatives }\end{array}$ \\
\hline $\begin{array}{l}\text { CE } 450 \\
\text { (Senior) }\end{array}$ & $\begin{array}{l}\text { Reinforced } \\
\text { Concrete Design }\end{array}$ & $\begin{array}{l}\text { Understand how material use } \\
\text { impacts sustainability in } \\
\text { reinforced concrete design. }\end{array}$ & $\begin{array}{l}\text { Understand methodologies to assess a } \\
\text { systems resilience, given a low } \\
\text { probable/high impact event. }\end{array}$ \\
\hline $\begin{array}{l}\text { CE } 460 \\
\text { (Senior) }\end{array}$ & $\begin{array}{l}\text { Geotechnical } \\
\text { Engineering } \\
\text { Design }\end{array}$ & $\begin{array}{l}\text { Appreciate the impacts of a } \\
\text { design alternative on } \\
\text { sustainability by determining } \\
\text { the environmental impacts }\end{array}$ & $\begin{array}{l}\text { Understand impact foundation design on } \\
\text { the resilience of a system }\end{array}$ \\
\hline
\end{tabular}




\section{DESIGN AND DEVELOPMENT OF MODULES}

Based on the findings from the review of literature, the research team developed a template for the ALMs to be used across all courses. This was done to ensure uniformity of the ALMs. The researchers hope that the similarity between the ALMs will help students better align these concepts with one another. Each ALM consisted of the following items:

1. Module description: A brief overview of the module, its contents and its purpose

2. Learning Objectives: Specific student learning objectives the module is focusing

3. Placement of the module within the course schedule: A suggestion to the instructor on where the module would fit within the course schedule

4. Topic description: Technical content of the learning module

5. Assessments: Methods to assess if the learning objectives are met

6. Pedagogy: Description of class activities the instructors could use to deliver the technical content in the class.

7. Bibliography: Full references of all articles cited in the technical content

Each ALM is also accompanied with a power point presentation of the technical content to provide instructors the option to deliver the technical content of the module by use of the traditional lecture style. Two ALMs were developed for each of the freshmen, sophomore, and junior courses selected for this project (please refer to Table 1). One of the ALMs focused on concepts related to sustainability while the other focused on resiliency. Design Tasks (DTs) were developed for the senior level classes.

\section{IMPLEMENTATION OF MODULES}

For the academic years, 2017-2018 and 2018-2019, several courses had either a portion, or all of the intended S\&R ALMs/DTs implemented. ALMs and DTs were introduced into each course syllabus based on space availability within the course lesson plans, and when students have sufficient understanding of the course material to be able to conceptualize sustainable or resilient concepts as applicable to that particular course.

The following sections explain in detail the experience from each of these implementations.

ENGR 120, Introduction to engineering design, had two rounds of implementation, one for each semester. Implementation covered two class periods, one on sustainability and one on resiliency. During each session an in-class activity was provided. For the fall semester, the sustainability class included discussion on the three pillars of sustainability (Environmental, Social, Economic), and focus on developing student understanding of the major concept of sustainability. To relate sustainability to engineering, the lecture focused on power generation systems and how they correlate to sustainable development. For the fall semester the resiliency lectures included covering the definitions of the key terms for resiliency, with emphasis on the four pillars of resilience (Robustness, Resourcefulness, Redundancy, and Rapidity). Assessment methods employed during the fall semester included in-class activities and exams. Each lecture was accompanied with an in-class activity where students formed groups and covered an example of infrastructure, and how sustainable, or resilient designs could be implemented into the system, and what expected results would be produced from such design changes. Exams administered during the fall semester included questions on the key terms and basic concepts of 
both resiliency and sustainability. Implementation of S\&R ALMs for the spring semester were conducted similarly as to that of the fall semester, with similar results.

CE 280 implemented only the sustainability ALM for both the fall semester, and both sustainability and resiliency ALMs for the spring semester. Implementation of the sustainability ALM consisted of providing a lecture on sustainability with accompanying power point presentation. Sustainability topic consisted of basic conceptual information as well as referencing the course text book which has one chapter dedicated to sustainable development in civil infrastructure. Proceeding the lecture an in-class discussion on the concepts of sustainability allowed for students in the class to openly give feedback and ideas as to what they understand of sustainable development. For the spring semester, the sustainability ALM was implemented similarly as to the fall semester's implementation with the addition of resiliency ALM lecture following the sustainability lecture. The in-class discussion for the spring semester revolved around both S\&R concepts. For assessment methods in CE 280, a homework assignment was given during the fall semester that corresponded to sustainability topics as well as two questions on the final exam that related to sustainability.

CE 282 implementation consisted of a lecture for the fall semester, and both a lecture and inclass activity during the spring semester. Only the sustainability ALM regarding Life Cycle Cost Analysis was covered for both semesters. For the spring semester, the in-class activity consisted of an example problem where students used given information on multiple design alternatives, and asked to compute the life cycle cost analysis for each alternative. Upon completion of the inclass activity, students engaged in an instructor-led group discussion on the results of the activity. For assessment methods, only the in-class activity work was collected.

CE 320 is only offered during the fall semester. was performed. Implementation consisted of a general concept lecture where the instructor followed the basic concept and terms offered in the ALMs for sustainability, and key terms for resiliency. Coverage of sustainability was linked with the CE 320 textbook, which has sustainability components provided throughout several chapters. Resiliency implementation covered the computational examples provided within the resiliency ALM. Assessment methods included a computational in-class group activity that covered both sustainability and resiliency. The sustainability assessment consisted of estimation of carbon emissions for various transportation scenarios, as well as how home power generation relates to carbon emissions. The resiliency computations consisted of integrating a provided function given certain boundary conditions to relate to loss of functionality given the occurrence of a hazardous event. Data collection and results from student work are discussed in outcomes and results section of this report.

CE 330 is only offered during the spring semester, at which time the implementation of the sustainability ALM was performed. Implementation only consisted of the sustainability ALM. The method of implementation was performed by lecture with accompanying Power Point. After the lecture an in-class activity was given to the students, in which they could either work individually or in groups. The activity consisted of comparing head loss and power generation in a section of pipe with varied pipe diameters and materials. The students were given design parameters such as wall friction, Reynold's number, fluid viscosity and flow rate. The goal is to show how the different materials (plastic, concrete, steel) and pipe size effects the flow and head 
loss of the fluid which in turn relate to sustainability of the use if right material type. Design requirements were then related to environmental and economic impact and how designers can consider sustainability in their designs by associated material use. A qualitative take-home activity was given to the students after the lecture, which covered a design scenario regarding sustainability concepts and how they link to CE 330. Data collection and results are discussed in the outcomes and results section of this report.

$\underline{\text { CE } 340}$ is only offered in the fall semester, at which time both sustainability and resiliency was covered. For each ALM, the lecture was a standalone lecture with a PowerPoint presentation and an instructor guided group discussion. The sustainability ALM was considered by the instructor easier to implement as the material cost and environmental impact are already covered in the regular course content. Resilience concepts were covered by relating mitigation methods for civil infrastructure during a disaster event. Methods of assessment included the use of concept maps. Students were given concept maps as a take home activity, and offered extra credit upon completion of the activity.

CE 360 is a spring only class, and both implementations for sustainability and resiliency ALMs were accomplished. The implementation of the ALMs covered two lecture periods. The first lecture covered the sustainability presentation, with a take home activity that discussed the conceptual implementation of sustainable design methods for geotechnical engineering. Special emphasis was made on the scope of contributions that can originate from geotechnical engineering primarily from material reuse and recycling. The second lecture that focused on resiliency aspects of engineering in general with examples of resilient geotechnical engineering. Students participated in a group discussion that focused on the various aspects of sustainability and resiliency that can be improved for a highway project from geotechnical engineering point of view. For assessment methods, the take-home assignments were collected, and two questions on S\&R definitions were administered on the final exam.

CE 370 is only offered during the spring semester, and both implementations for sustainability and resiliency ALMs were accomplished. The implementation of the ALMs covered two lecture periods. The first lecture covered the sustainability presentation, with a take home activity that discussed the conceptual implementation of sustainable design methods for a theoretical transportation system. Students were given a primer that discussed the potential roadway system that needed renovation, and were instructed to list potential methods of construction or design that would aid the overall sustainability of the system. The second lecture covered the resiliency ALM presentation with a take-home activity that discussed conceptual resiliency topics for a theoretical transportation system. Students were also given a presentation on how to construct concept maps using the CmapTools software. Students were then given the option to perform a conceptual map for both sustainability and resiliency for extra credit. For assessment methods, the take-home assignments were collected, and two questions on S\&R definitions were administered on the final exam.

CE 425 is a spring class and will have a partial implementation of the sustainability DT in Spring 2020. In this module, students perform a design task which is intended to provide students with a practical method for analyzing two design alternatives, supporting decision making about the sustainability of each. Students will also be able to search for and find alternate environmental, 
social, and/or economic key factors that may impact sustainability Students were required to complete a reading assignment to familiarize themselves with the task before participating in the class.

$\underline{\text { CE } 440}$ is only offered in the fall semester, and had a partial implementation of the sustainability ALM during the fall semester. The partial implementation included one lecture on the basic concepts of sustainability as well as a student hand-out that covered terms and definitions of sustainability concepts. Students were given several handouts with terms and definitions on sustainability, and instructed to research on their own further explanation on sustainability in pavement design.

During the spring semester, $\underline{\mathrm{CE}} 450$ implemented the sustainability design task, as well as a brief lecture on resiliency concepts pertinent to reinforced concrete design. An additional method to increase the comprehension of sustainability in civil infrastructure was employed beyond the normal construct of the S\&R implementation. The addition was qualitative assignment that was given to students. The assignment was to research sustainability in reinforced concrete design methods, then construct a written paper on findings. For the design task, a comparison example was made between two reinforcement types, conventional and alternative, and the associated embodied energy and embodied carbon with each. This was completed after students were familiar with the basic design concepts for reinforced concrete. Students designed a concrete beam under a given loading condition, using conventional methods discussed in the normal content of the course. After the initial design of the concrete beam, students then investigated alternative reinforcement types, such as basalt reinforcement, or carbon fiber reinforcement and then redesigned the concrete beam using the new type of reinforcement. Upon completion of the task, a discussion on the benefits and tradeoffs between using each type of reinforcement was made. Collection of the assessment material was retained in the data collection, and is discussing in the results section of this report.

CE 460 implemented the sustainability design task during the fall semester and was voluntary for extra credit. The sustainability design task consisted of comparison of two pile foundation designs, one driven and one drilled shaft. The students were instructed to design each pile type, then determine the volume of material required for each pile design, as well as the volume of soil required to remove during placement of the piles. Students were then given embodied energy and embodied carbon factors to multiply to the volumes of each material type to compute either the embodied energy or embodied carbon for each design. A discussion was then required on the tradeoffs between each method of foundation design. Impact and results are discussed in the results section of this report.

\section{RESEARCH METHODS AND FINDINGS}

A major goal of this project is to positively shape students' knowledge, attitudes, and behaviors related to sustainability and resiliency within civil engineering. To assess these changes, we interviewed students after completing modules in the aforementioned courses to understand the developmental trajectory of students' understanding of S\&R content and practices . We emailed students enrolled in the courses inviting them to participate in an interview related to their 
knowledge of sustainability and resiliency, and interviewed those students that responded. Participants received a \$20 gift card in appreciation of their time.

To guide the interviews, we developed a semi-structured interview protocol. The interviews explored students' experiences learning about sustainability and resiliency in each of the civil engineering courses they had taken up that point and describing their understanding of sustainability and resiliency. The interviews also focused on the participants' definitions of and perceptions of how sustainability and resiliency relate to the work of practicing civil engineers, and how they plan to use what they know about S\&R as a civil engineer. The interviews lasted between 15 and 50 minutes in length, depending on the depth of students' experiences with sustainability and resiliency, and their willingness and ability to talk about those experiences. All interviews were recorded and transcribed verbatim.

We analyzed the interviews inductively using sensitizing concepts[5] derived from the literature on sustainability and resiliency. The interviews were open-coded to capture the different ways that the participants understood and encountered sustainability and resiliency concepts, followed by axial-coding to group similarly coded material together both within and across the transcripts included in the dataset to identify important themes. A total of 32 interviews were made to date. Figure 1 presents preliminary student interview data showing various levels of understanding of sustainability and resiliency concepts.

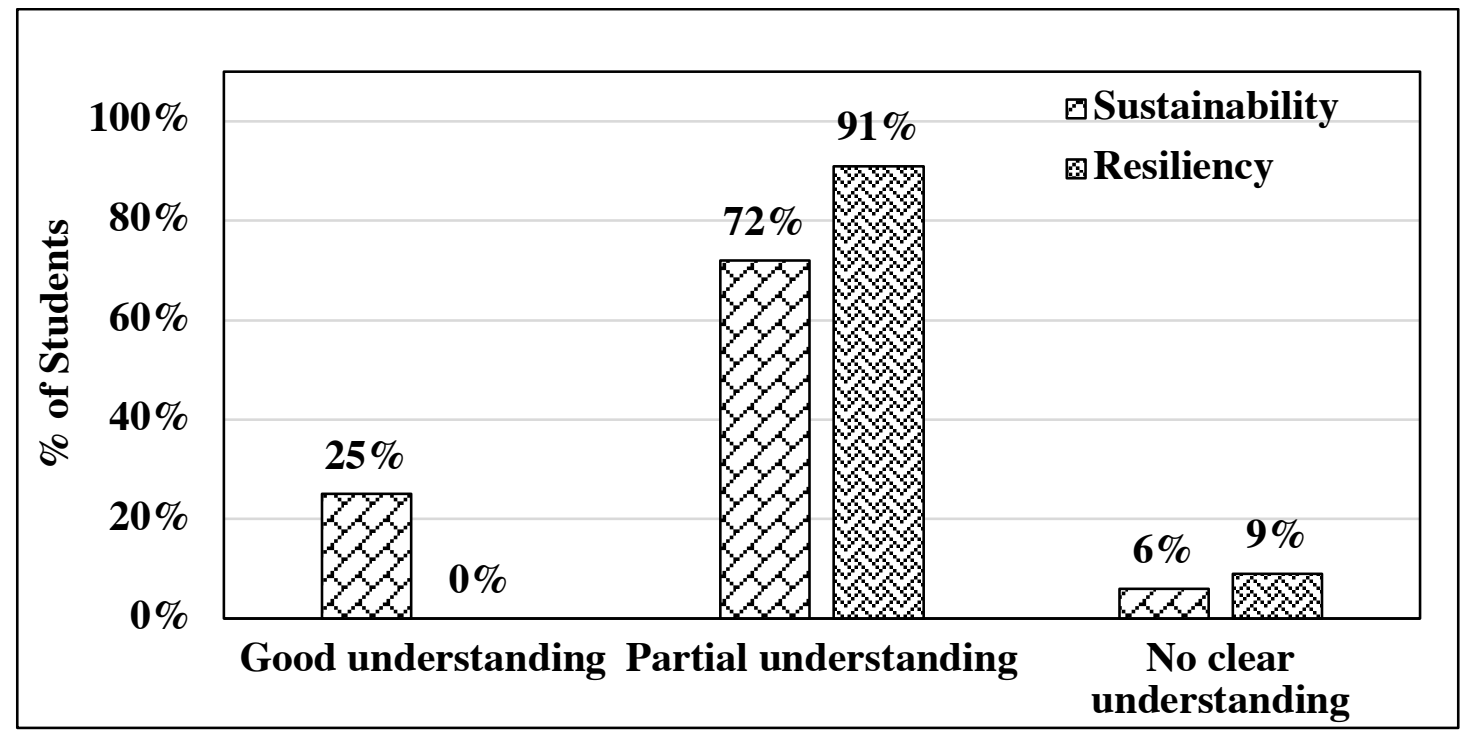

Figure 1 Student interviews data showing sustainability and resiliency understanding

Preliminary results of our analysis yielded several themes related to sustainability and resiliency. The participants varied widely in their understanding of sustainability and resiliency. For some students, sustainability was simply another word for environmentalism that focuses on reducing the impact of engineering practices on the natural world. Other students presented a commonly held definition of sustainability as "meeting the needs of the present without compromising the needs of future generations." Students with more sophisticated understandings of sustainability recognized that it involves tradeoffs between economic, environmental, and social factors, with social factors being the least mentioned or understood by the participants. 
Students were much less articulate with regards to their definitions and understanding of resiliency. Some students viewed it as the same as sustainability or focused on resiliency as it relates to longevity. Other students presented more nuanced descriptions of resiliency, recognizing that it related to the ability of a system to recover from adverse events, and identifying factors such as redundancy and resourcefulness that can reduce the time of recovery. While most students were able to identify a relationship between sustainability and resiliency, particularly as it related to the longevity of a design, they struggled to recognize the tradeoffs and tension in balancing sustainability and resiliency.

Finally, repeated exposure to sustainability and resiliency concepts and practices throughout the curriculum helped students to recognize their importance in the work of practicing civil engineers. The active learning modules both reinforced the importance of sustainability and resiliency for those students who already valued these approaches and helped students who had not considered issues surrounding $\mathrm{S} \& \mathrm{R}$ to better understand these issues and commit to addressing them as part of their work as practicing engineers.

\section{CONCLUSION}

This project explored how sustainability and resiliency concepts and design practices can be threaded through all four years of an undergraduate civil engineering curriculum. By scaffolding instruction on sustainability and resiliency throughout the curriculum, students graduate with the knowledge and skills to implement sustainable and resilient designs, and appreciate the importance of the topics to the work of practicing civil engineers. Future work will include exploring how the active learning module approach described in this paper can be applied to other engineering disciplines, and implementing similar curricular reforms at other departments and schools of civil engineering. 


\section{REFERENCES}

[1] P. Bocchini, D. M. Frangopol, T. Ummenhofer, and T. Zinke, "Resilience and sustainability of civil infrastructure: Toward a unified approach," J. Infrastruct. Syst., 2014.

[2] C. Davidson, B. Allenby, and J. Crittenden, "Center for Sustainable Engineering." [Online]. Available: https://csengin.syr.edu/electronic-holdings-library/. [Accessed: 02Mar-2020].

[3] "Sustainable Engineering Education Key Resources Repository (SEEKRR)." [Online]. Available: http://www.aimehq.org/resources/seekrr. [Accessed: 02-Mar-2020].

[4] J. Crittenden, C. Hendrickson, and B. Wallace, ICSI 2014. American Society of Civil Engineers, 2014.

[5] M. Q. Patton, Qualitative Research \& Evaluation Methods: Integrating Theory and Practice. SAGE Publications, 2014. 